\title{
Impacts of Climate Change on Agriculture and Changing Adaptive Strategies in the Coastal Area of Lakshmipur District, Bangladesh
}

\author{
MOHAMMAD ABUL HASNAT ${ }^{1}$, NAZMUL HOSSAIN ${ }^{2 *}$, \\ MUHAMMAD MUHIBBULLAH ${ }^{1}$, MD IQBAL SARWAR ${ }^{1}$ and TANJIA SHORMIN ${ }^{2}$
}

'Department of Geography and Environmental Studies, University of Chittagong, Chittagong-4331, Bangladesh. ${ }^{2}$ Department of Soil Science, University of Chittagong, Chittagong-4331, Bangladesh.

http://dx.doi.org/10.12944/CWE.11.3.03

(Received: July 20, 2016; Accepted: September 04, 2016)

\begin{abstract}
The coastal area of Bangladesh is topographically susceptible to disaster where climate change addresses a new depressing effect to coastal agriculture. The main objective of the present study was to explore the impacts of climate changes on agriculture and changing adaptive strategies in the coastal area of Lakshmipur in Bangladesh. Primary data were collected through field observation survey, questionnaire survey and Focus Group Discussion (FGD). To conduct the questionnaire survey, around 120 respondents have been selected randomly from the coastal areas of Ramgati and Kamal Nagar upazilla under Lakshmipur district. The whole survey was conducted during monsoon and winter seasons in the month of March 2014 to February 2015. The present study was carried out through primary and secondary sources of data collection. Field observation survey, questionnaire survey and Focus Group Discussion (FGD) (during March, 2014 to February, 2015) were accomplished for collecting primary data. The questionnaires contained structured and close ended questions to collect the information through face to face interview from the respondents. Secondary data were collected from Bangladesh Meteorological Department (BMD). Collected data were processed and analyzed by the help of Statistical Package for the Social Sciences (SPSS: version-16) and map of study area were prepared by Arc GIS 9.1 software. The results revealed that about $87.5 \%$ of respondents have experienced climate change and its impact on their agriculture gradually from 40 years. They also perceived increase in temperature, drought, flood, cyclone and salinity intrusion, rain less winter season, long summer season, unpredictable rainfall, and changing the monsoon respectively. About $96.6 \%$ respondents perceived decrease in rainfall. Results also revealed that about $53 \%$ of respondents experienced severe intensity of major climate change induced disasters. Furthermore, $9 \%$ respondents experienced little bit severity. Agricultural crops cultivation is changing from previous time due to the climate changing events and decreasing crop production due to their damaging effects. Almost $40 \%$ of respondents in the study area were not familiar with coping strategy in response to climate change. They tried to adjust and cope with cultivation of short duration crops, introducing new variety and making embankment. To minimize the effects of climate change short duration crops, new variety and making embankment for crop cultivation need to adopt in study area.
\end{abstract}

Keywords: Adaptation, Agriculture, Climate Change, Coastal Area, Disaster, Impact.

\section{INTRODUCTION}

Since agriculture is the dominant sector of the economy of Bangladesh, climate change concerned a serious issue. This sector contributes roughly 20 percent to Gross Domestic Product (GDP), where crops representing $11.2 \%$, livestock $2.7 \%$, fisheries $4.5 \%$, and forestry $1.8 \%^{1-2}$. Furthermore, this sector provided about $50 \%$ employment of the labor force during 2001 to $2010^{1}$. Because of 
dependency on rain-fed, poverty, lack of skilled labor forces, inequitable land distribution and poor infrastructure; the agriculture of Bangladesh is dependent on weather and for that reason it is highly vulnerable to climate change ${ }^{3}$.

Bangladesh is located between $20^{\circ} 34^{\prime}$ to $26^{\circ} 38^{\prime} \mathrm{N}$ latitude and $88^{\circ} 01^{\prime}$ to $92^{\circ} 42^{\prime} \mathrm{E}$ Longitude and occupies an area of $147,570 \mathrm{~km}^{2}$ with a coastal area of $47,211 \mathrm{~km}^{2}$, which contains $32 \%$ of its total land mass ${ }^{4}$. The coast of Bangladesh is approximately $711 \mathrm{~km}$. long which has a very low-laying flat topography. About $62 \%$ of the land comprising an elevation less than 3 meters $^{5}$. It is one of the most populated countries in the world and the population of the coastal zone of Bangladesh is 35.1 million in $2011^{6}$. Bangladesh is one of the top 10 nations that are mostly vulnerable to climate change ${ }^{7}$ due to its low-lying and flat topography in southeastern region, subjected to riverine flooding (due to sea level rise), frequent cyclones, storm surge, heavy rainfall, tornados, river bank erosion, salinity, high population density, high level of poverty, and solely reliance of livelihoods on climate-sensitive sectors $^{8-12}$.

World Bank ${ }^{13}$, has projected that the sea level would rise up to $10 \mathrm{~cm}, 25 \mathrm{~cm}$ and $1 \mathrm{~m}$ respectively by the year 2020, 2050 and 2100 in Bangladesh. The latest IPCC ${ }^{14}$ provided a scenario where they stated that, sea level will rise 9 to $88 \mathrm{~cm}$ by the year 2100 . Sea level rise could potentially make 33 million refugees by 2050 and up to 43 million by $2080^{15}$ in Bangladesh. According to IPCC ${ }^{16}$, the mean annual temperature will rise $3.3^{\circ} \mathrm{C}$ per century. Global Circulation Model (GCM) results predict an average temperature increase of $1.0^{\circ} \mathrm{C}$ by 2030 and $1.4^{\circ} \mathrm{C}$ by $2050^{16}$. The BUP-CEARS-CRU ${ }^{17}$, study reported a $0.5^{\circ} \mathrm{C}$ to $2.0^{\circ} \mathrm{C}$ rise in temperature by the year 2030 in Bangladesh. According to Climate Change Cell, ${ }^{9}$ monsoon rainfall may increase by $11 \%$ by 2030 and $27 \%$ by 2070 , where the BUP-CEARS$\mathrm{CRU}^{17}$, found $10 \%$ to $15 \%$ rise in average monsoon rainfall by the year 2030. Some studies found the increasing trend of rainfall in the wet monsoon season and decrease in the dry winter and spring months ${ }^{18-19}$. A combination of increased temperature and reduced rainfall results in an increase in evapotranspiration which is detrimental to crop growth ${ }^{9}$ in Bangladesh. Food and Agriculture Organization of the United Nations [FAO $]^{20}$, forecasted that dry season rainfall may decrease $37 \%$, and the risk of droughts will increase significantly. Drought hampers land preparation and ploughing activities, delaying the seed sowing and the transplantation of crops. Crops which are grown in rabi (dry) season are adversely affected by drought. The drought in 1973 was labeled 'the worst in recent history, the drought in 1979 was dubbed 'the worst in living memory, ${ }^{21}$ and the drought in 1994-95 called 'the worst in this century'22 in Bangladesh. Because of unavailability of relevant data, the figures on the annual drought related loss of crop production cannot be presented except for the 1982 drought. The total loss of rice production due to drought in 1982 was 52,896 metric tons ${ }^{23}$. Climate change has also increased the extent of monsoon flooding ${ }^{24}$. Long durational flood reduces agricultural production and causes death of livestock ${ }^{25-27}$. The salinity intrusion is also a cause of soil fertility reduction and decline rice yields ${ }^{28-29}$ in coastal areas of Bangladesh. Tropical cyclones hit Bangladesh 29 times in the second half of the last century, with one of the most devastating for taking 138,000 lives in April $1991^{30}$. The devastating tsunami that occurred in 2004, hurricane KATRINA in 2005, cyclone SIDR in 2007 and NARGIS in 2008, which killed millions of people in coastal areas, are obvious recent examples of climatic extremes and the associated vulnerabilities of coastal residents ${ }^{31}$. These cyclones and storms have both immediate and long term effects on coastal agriculture of Bangladesh ${ }^{12}$.

Climate change reduces crop production and increasing food insecurity in Bangladesh ${ }^{19}$. Karim et al ${ }^{27}$, reported that the 1988 flood reduces 45 $\%$ agricultural production. Salinity intrusion caused by sea level rise significantly reduces rice yield in coastal area ${ }^{29}$. Study of World Bank ${ }^{13}$, suggests that increasing salinity and 0.3 meter sea level rise will cause a net reduction of 0.5 million metric tons of rice with declining soil productivity for several years. Among the productive sectors damage was highest ( 0.43 Million USD) in agriculture for cyclone SIDR in 2007. According to the latest estimates, about 800,000 to 1300,000 MTs of paddy have been destroyed in SIDR which created severe food insecurity among the affected people ${ }^{32}$. It is predicted that due to climate change events production of rice and wheat will reduce $8.8 \%$, and $32 \%$ respectively 
within $2050^{33}$ as well as $30 \%$ in $2100^{\circ}$. Considering all these (direct and induced) adverse effects of climate change on agriculture, it can be said that production of crop is a substantial challenge in producing enough food in Bangladesh ${ }^{13,34-36}$, and agriculture in Bangladesh is in a indescribable threat ${ }^{8,37-38}$.

To handle any aversive condition we need to adapt with the situation. Maddison ${ }^{39}$, argues that if farmers learn gradually about the change in climate, they will also learn gradually about the best adaptation options towards it. According to him, farmers learn about the best adaptation options through three ways: (1) learning by doing, (2) learning by copying and (3) learning from instruction. So, farmers' perceptions of climate change need attention for the success of agricultural production. The adaptation to climate change is highly required in order to cope with this concurrent problem. But for the limitation of economic support, lack of technical instruments, lack of sufficient development institute the adaptation options could not be followed effectively. The present research paper is tried to empirically analyze the impacts of climate change focused on agricultural practices, problems due to climate change effects along with adaptation capacity and coping strategies in the study area. Finally, the study also suggested some probable adaptive strategies to cope with the adverse effects of climate change effectively in favor of coastal zone of Bangladesh.

\section{MATERIALS AND METHODS}

A total number of 19 districts (including 129 Upazilla) out of 64 in Bangladesh are treated as the coastal areas, which are adversely affected

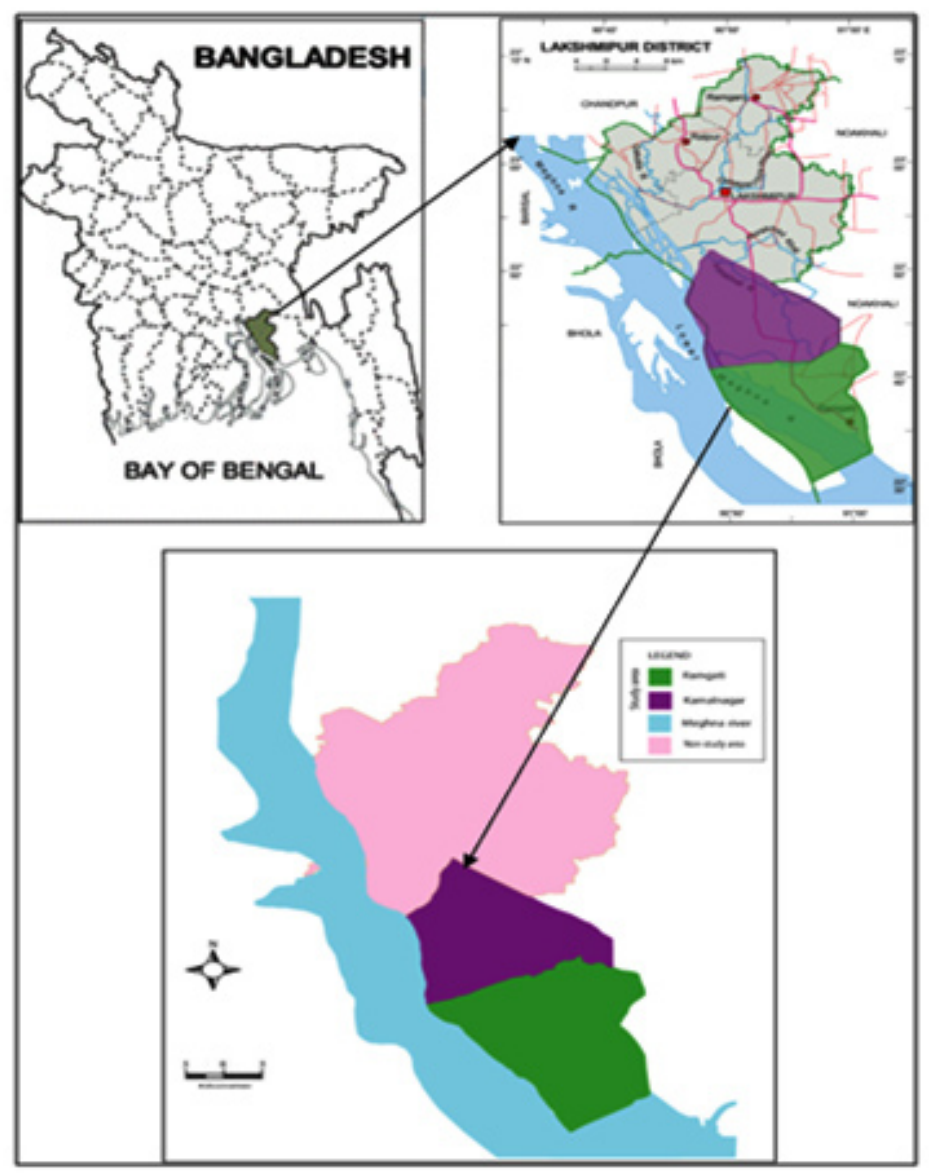

Map 1: Location of the study area Source: Base map was collected from BBS $^{40}$ 
by climate change exposures ${ }^{41}$. Among them, the Ramgati and Kamal Nagar upazilla under Lakshmipur district were selected for the present study (Map 1). These two upazila were selected on the basis of vulnerability of climate change. Some parameters were considered to assess the climate change such as; prolong inundation, increase of salinity, loss of land due to river bank erosion and frequent climatic disasters like cyclone and seasonal flooding.
Both the Ramgati and Kamal Nagar upazila comprises with an area of $594.74 \mathrm{~km}^{2}$ and almost all of the areas are situated at the lower Meghna riverine flood plain ${ }^{42}$. The study area comprises of $4,64,000$ people with 820.5 density per $\mathrm{km}^{2}$ and 1 , 01,736 households size is almost 4.76 person per household ${ }^{42}$. Total 120 respondents were selected as sample (local households as stakeholders) for conducting the questionnaire survey by random sampling technique. The stakeholders (farmer,
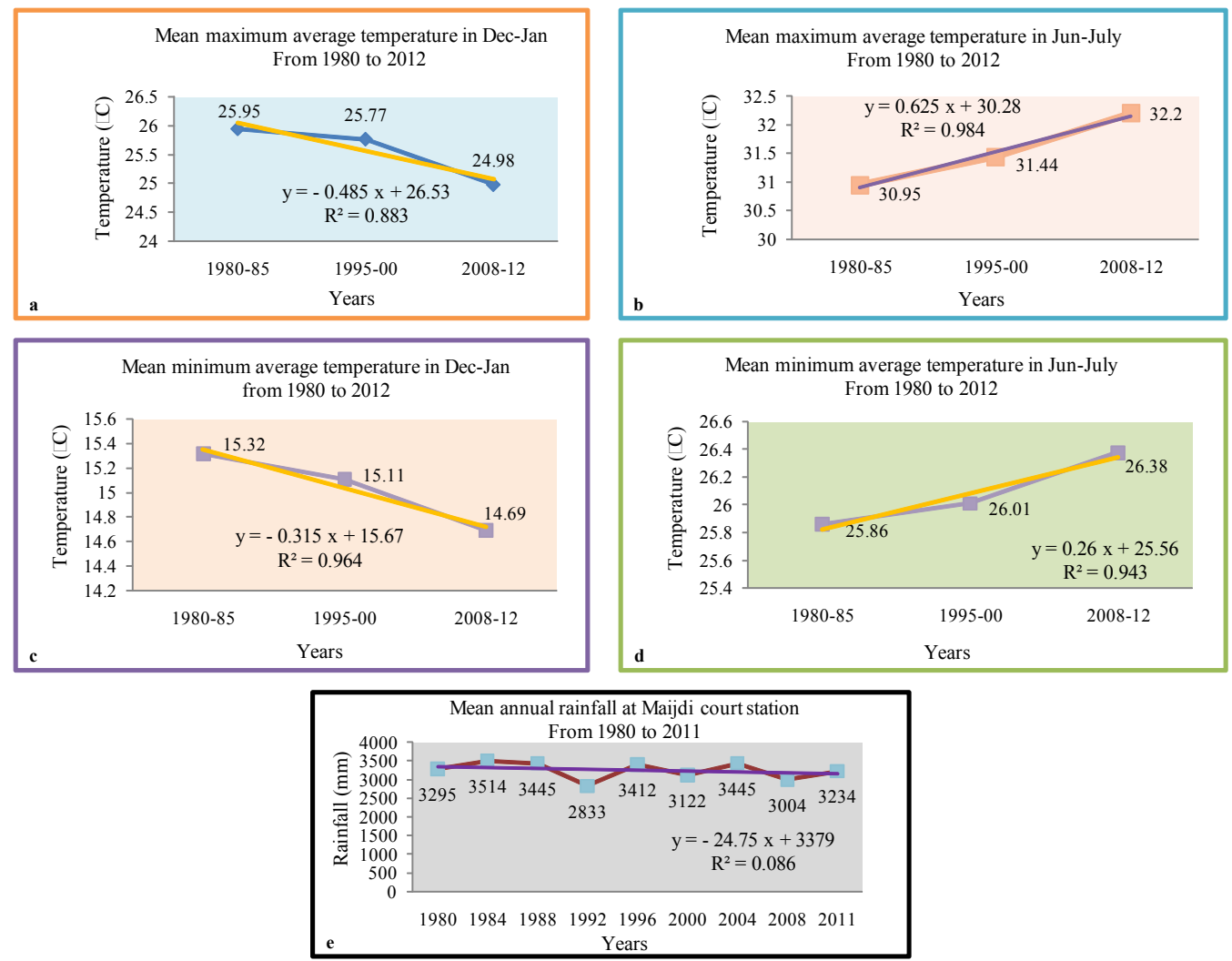

a) Mean maximum average temperature in Dec-Jan from 1980 to 2012 at Maijdi Court station of Bangladesh

b) Mean maximum average temperature in Jun-July from 1980 to 2012 at Maijdi Court station of Bangladesh

c) Mean minimum average temperature in Dec-Jan from 1980 to 2012 at Maijdi Court station of Bangladesh

d) Mean minimum average temperature in Jun-July from 1980 to 2012 at Maijdi Court station of Bangladesh

e) Mean annual rainfall from 1980- 2011 at Maijdi court station of Bangladesh

Source: Data were collected from Bangladesh Meteorological Department (BMD)

Fig. 1: Scenario of climate change (temperature and rainfall) in the study area 
housewife, primary school teacher, NGOs' worker, local social leaders, students and workers) were chosen from the victims of climate change in the study area.

Table 1 shows the socio-economic conditions of the respondents' of our study areas. About $95.83 \%$ respondents were above 40 years old and most of them were male (85\%). Most of the respondents were illiterate $(45 \%)$, and majority of the people were living in temporary housing systems (about $77.5 \%$ ) and they were living in their own house $(55.83 \%)$. About $54.17 \%$ of the respondents were living beside the river coast and most of them were farmer $(65.00 \%)$. Almost twothirds of the respondents (68.33\%) had household incomes within Tk 3,000-5,000 per month, which was below the poverty line. Not only the economic condition of people but also the geographical location of Lakshmipur district has imposed the highest level of vulnerability and climate-disaster risk to its population.

The present study was carried out through primary and secondary sources of data collection. Field observation survey, questionnaire survey and Focus Group Discussion (FGD) (during March, 2014 to February, 2015) were accomplished for collecting primary data. The questionnaires contained structured and close ended questions to collect the information through face to face interview from the respondents.

Secondary data were collected from Bangladesh Meteorological Department (BMD). Collected data were processed and analyzed by the help of Statistical Package for the Social Sciences (SPSS: version-16) and map of study area were prepared by Arc GIS 9.1 software.

\section{RESULTS AND DISCUSSION}

\section{Climate Change Induced Vulnerability in the Study Area}

The main concern of this study was to identify the climate change induced disasters, its impacts on agriculture in the coastal areas and coping strategies used by the victims of different disasters. According to United States Agency for International Development [USAID] ${ }^{43}$, risk from hazards of a community's depends on the frequency and severity of hazards and their vulnerability. So, the types of climate change disasters responses by communities are essential. According to Ali and $\mathrm{Ahmad}^{44}$, climate of coastal region are regulated by the location (Himalayas in north and Bay of Bengal in south) of Bangladesh. The impacts of climate change on Bangladesh are significantly visible particularly in coastal areas of Bangladesh which are on the front line of climate change ${ }^{45}$.

In fig. 1 we have presented the scenario of climate change (temperature and rainfall) in the study area. Data were collected from the Maijdi Court station which is one of the meteorological stations in the southeast region of Bangladesh and very nearer to the study area.

Fig. 1 represents that mean maximum temperature $(88.30 \%)$ and minimum temperature (96.40\%) in December- January (winter season) significantly decreased (fig. a and c). On the other hand both mean maximum $(98.40 \%)$ and minimum temperature $(94.30 \%)$ in June- July (monsoon season) has been significantly increased (fig. b and d). Fig. 1e shows that mean annual rainfall during the year of 1980 to 2011 has been slowly decreased $(8.60 \%)$.

In the present study respondents were asked a dichotomous ("yes/no" response) question about whether or not they had perceived climate changes in their living area within the last 40 years. In the responses to this question about $87.5 \%$ of respondents had experienced climatic change within the last 40 years. After their initial response, they were additionally asked about their perceived experience to a series of climatic events that are commonly associated with the global climate change effects in Bangladesh and their perceptions for individual climatic events are presented in Table 2.

It is observed from the Table 2 that almost $100 \%$ respondent perceived to increase in temperature, drought, flood and cyclone occurred in the study area where as, $96.6 \%$ respondents perceived rainfall decrease in the study area. About $85.5 \%$ people perceived increase in salinity intrusion, $85.2 \%$ in rain less winter season, $92.0 \%$ in long summer season, $90.9 \%$ in unpredictable rainfall, 
Table 1: Socio-economic condition of the respondents $(f=120)$

\begin{tabular}{|c|c|}
\hline $\begin{array}{l}\text { Socio-economic } \\
\text { parameters }\end{array}$ & $\begin{array}{l}\text { Respondents } \\
\text { (\%) }\end{array}$ \\
\hline \multicolumn{2}{|l|}{ Age } \\
\hline Below 40 years & 4.17 \\
\hline $41-50$ years & 40 \\
\hline $51-60$ years & 45 \\
\hline Above 60 year & 10.83 \\
\hline \multicolumn{2}{|l|}{ Gender } \\
\hline Male & 85 \\
\hline Female & 15 \\
\hline \multicolumn{2}{|l|}{ Education } \\
\hline Illiterate & 45 \\
\hline Below Secondary (I-X) & 24.17 \\
\hline Secondary (IX-X) & 12.5 \\
\hline Higher Secondary (XI-XII) & 9.17 \\
\hline Bachelor & 7.5 \\
\hline Masters & 1.67 \\
\hline \multicolumn{2}{|l|}{ Housing Condition } \\
\hline $\begin{array}{l}\text { Temporary structure } \\
\text { (made of Bamboo, straw, } \\
\text { wood, and mud) }\end{array}$ & 77.5 \\
\hline $\begin{array}{l}\text { Semi-permanent structure } \\
\text { (made of tin, bamboo, and brick) }\end{array}$ & 18.33 \\
\hline $\begin{array}{l}\text { Permanent structure } \\
\text { (made of brick, concrete) }\end{array}$ & 3.33 \\
\hline Other's & 0.83 \\
\hline \multicolumn{2}{|l|}{ House Ownership } \\
\hline Own & 55.83 \\
\hline Rental & 0 \\
\hline From Parents & 44.17 \\
\hline Gift & 0 \\
\hline \multicolumn{2}{|l|}{ Causes of Living } \\
\hline Education & 0 \\
\hline Business & 0 \\
\hline Service & 2.5 \\
\hline House Rent Low & 0 \\
\hline Own House & 76.67 \\
\hline Others (River bank Erosion) & 20.83 \\
\hline \multicolumn{2}{|l|}{ Location of the House } \\
\hline Beside the road & 19.17 \\
\hline Beside the River Coast & 54.17 \\
\hline Beside the canal & 0 \\
\hline Surrounded by Forest & 2.5 \\
\hline Others & 24.17 \\
\hline \multicolumn{2}{|l|}{ Occupation } \\
\hline Teacher & 3.33 \\
\hline Service & 4.17 \\
\hline Business & 11.67 \\
\hline Farmer & 65 \\
\hline Housewife & 14.17 \\
\hline Others & 1.67 \\
\hline \multicolumn{2}{|l|}{ Income Level Per Month } \\
\hline 3,000-5,000 BDTk & 68.33 \\
\hline $5,001-10,000$ BDTk & 14.17 \\
\hline $\begin{array}{l}\text { Above } 10,000 \text { BDTk } \\
\text { (maximum income is } 20,000 \text { BDTk) } \\
\text { ( } 78.33 \text { Tk }=1 \text { US } \$ \text { as of Feb 2015) }\end{array}$ & 17.50 \\
\hline
\end{tabular}

and $80.7 \%$ in changing the monsoon. Respondents were also responded to the intensity of climate change induced disasters. It is also found from the survey that $53 \%$ respondent urged that the intensity of major climate change induced disasters was very severe whereas only $9 \%$ of respondents were given their opinions as opposite thinking (not in Table 2).

Increase of temperature globally was also observed by ${ }^{46-51}$. In regards, SAARC Meteorological Research Council [SMRC] $]^{52}$, observed an increasing trend of mean maximum and minimum temperature in some seasons, as well as overall trend of increasing the annual mean maximum temperature over the period of 1974-2012 in coastal areas of Bangladesh. Annual mean temperature from 1948 to 2008 and rainfall from 1970 to 2010 had been gradually changed ${ }^{53}$ in Bangladesh. Drought mostly affects in during the pre-monsoon and post-monsoon periods and rice production reduces in 1982 due to drought in Bangladesh ${ }^{23}$. Impacts of coastal flooding were investigated by several researchers ${ }^{27,54-57}$. Previous studies found that frequent cyclones hit the coastal belt of Bangladesh ${ }^{57-60}$. In a study Rahman and Alam $^{28}$, found that the salinity intrusion is also increasing in the coastal areas of Bangladesh. Rain less winter season was similarly also found by ${ }^{18-19}$. Unpredictable rainfall was also observed by ${ }^{59,37}$. There is an evidence of $5-10 \%$ increase in intensity (wind speed) that would contribute to enhance storm surges and coastal flooding, and also project $20 \%$ increase in intensity of associated precipitation that would contribute to flooding ${ }^{37}$. Cyclone winds also increases in intensity because of the positive correlation with sea surface temperature ${ }^{61}$. In addition, Sarker and Hossain ${ }^{57}$, found that the river bank erosion, tidal surge and tropical cyclone were the most common disasters according to the people's perception in same study area. Intensity of these disasters was increasing with time ${ }^{57}$. Especially the riverbank erosion and tidal surge had increased significantly in the study area ${ }^{57}$. These evidences are similar with the perceptions of our respondents of this present study.

\section{Major Agricultural Practices in the Study Area}

It is observed from the survey that various agricultural activities are familiar and primary economic activity is dominated in the study area. Different types of field agriculture, fishing, poultry 
rising and community level crops are cultivated in the study area. Along with paddy various types of food crops like oil, pulse seeds and vegetables are also cultivated by the local farmers in the study area. Among them Soybean, Ground Nut, Sugarcane, Pea, Lentil, Gram, Mustard, Chili, Potato and various fruits \& vegetables are mentionable. It is established from the FGD and field survey that, food crops and oil seeds were vastly cultivated after cereal crops commonly since last decade but recently it is going to be decreased and recently vegetable cultivations are rapidly increasing. These types of changes are being happened mostly due to climate change effects, adopting of HYV and market demand of cost benefit approaches, agricultural systems changes through time. It is also mentionable that many traditional and local grain and food crops cultivation and community level common agricultural practices were drastically fall down due to effects of climate change in the study area. Sarker and Hossain ${ }^{57}$ had also claimed that the traditional paddy and pulse crops productions were decreasing. A comparative scenario of crop production status during the last few decades is shown in the following Fig. 2.

It can be stated from the fig. 2 that vegetable oriented combined crop production and cultivation area are gradually increasing against oil oriented food crops from the decade of 1974-1984 to 20052014. As a result vegetable oriented food cultivation increased in almost double than that of oil seeds oriented food cultivation which decreased by $12 \%$ (fig.2).

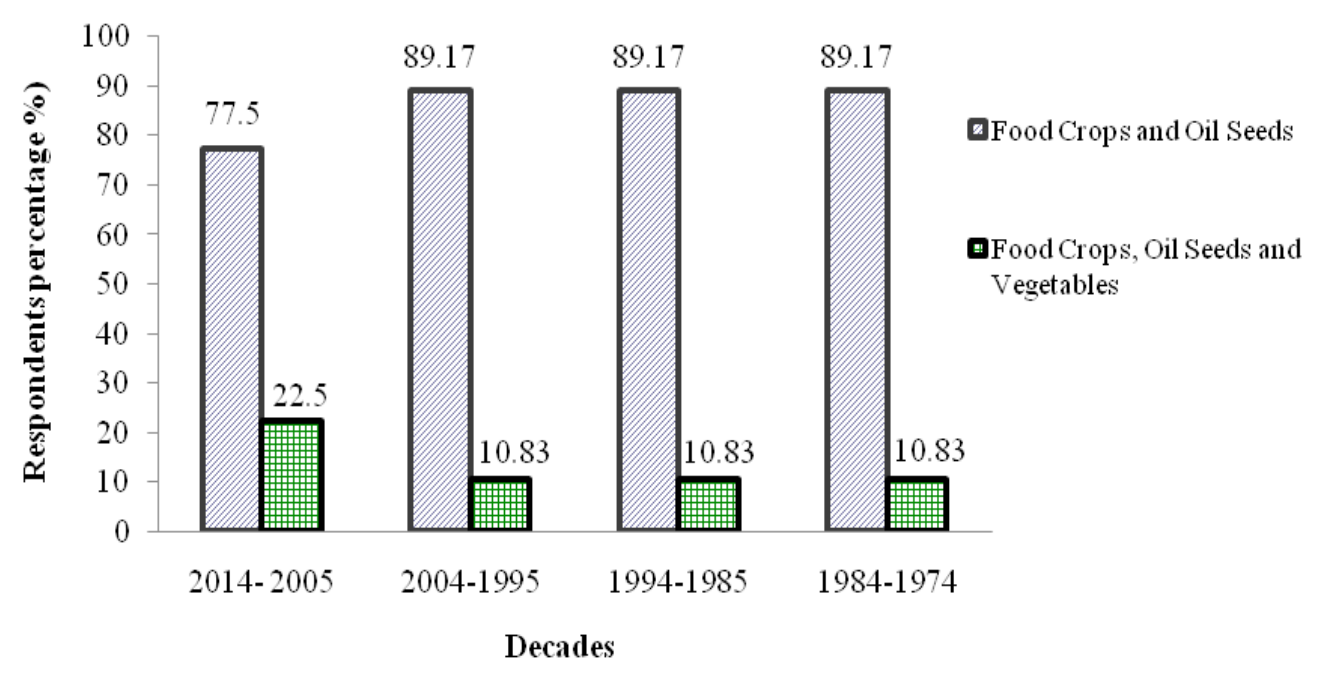

Fig. 2: Major cultivated crops in the study area; [Source: Questionnaire Survey, 2014]

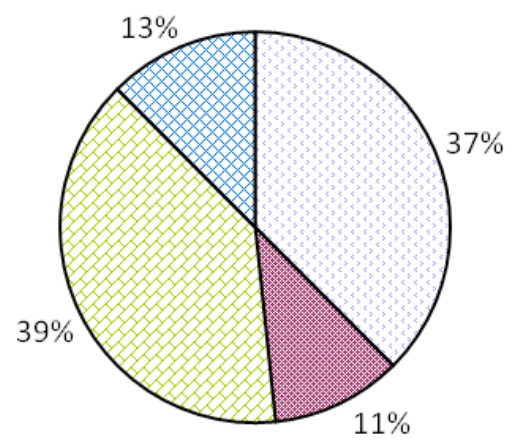

$\square$ River Bank Erosion

圆 Loss of Soil Fertility

$\square$ Loss of Land

QIncrease Soil Salinity

Fig. 3: Major causes responsible for disappearing crops in the study area; [Source: Questionnaire survey, 2014] 


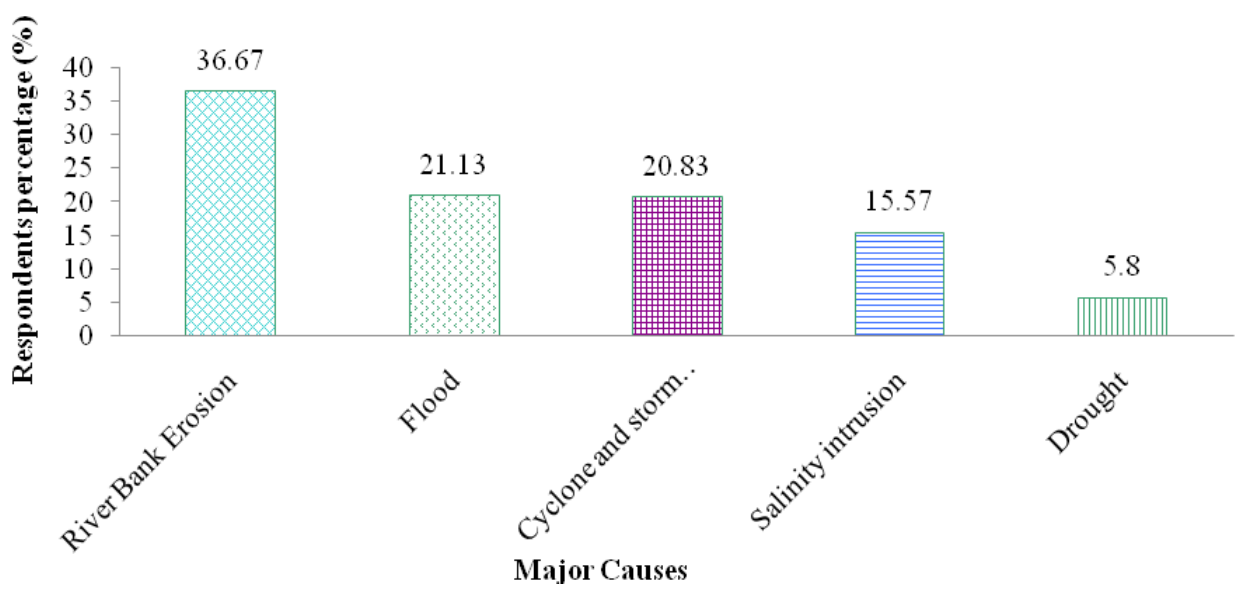

Fig. 4: Major negative causes which are responsible for low production of crops in the study area; [Source: Questionnaire survey, 2014]

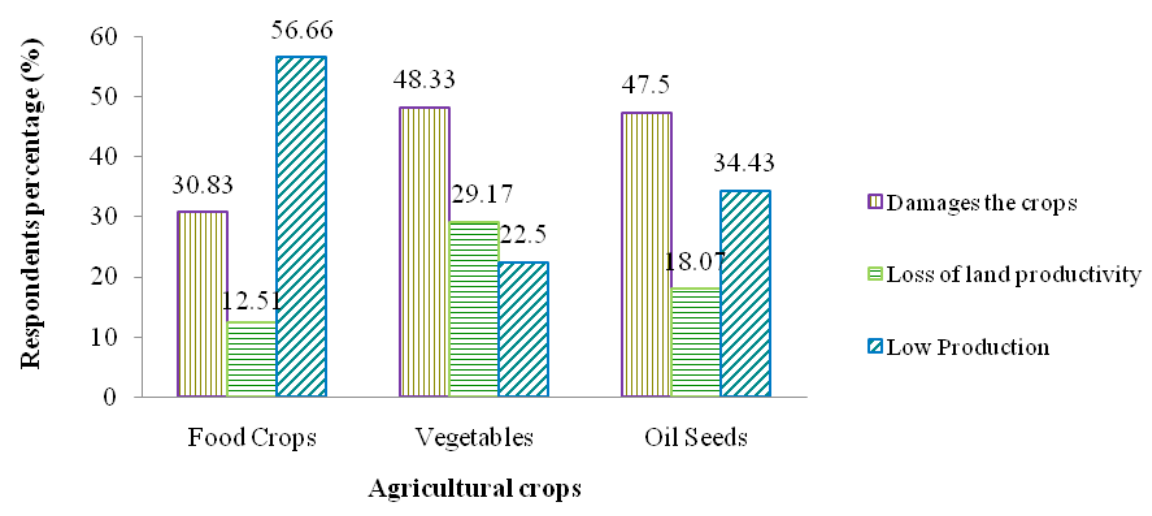

Fig. 5: Visible adverse effects of climate change on different crops in the study area; [Source: Questionnaire survey, 2014]

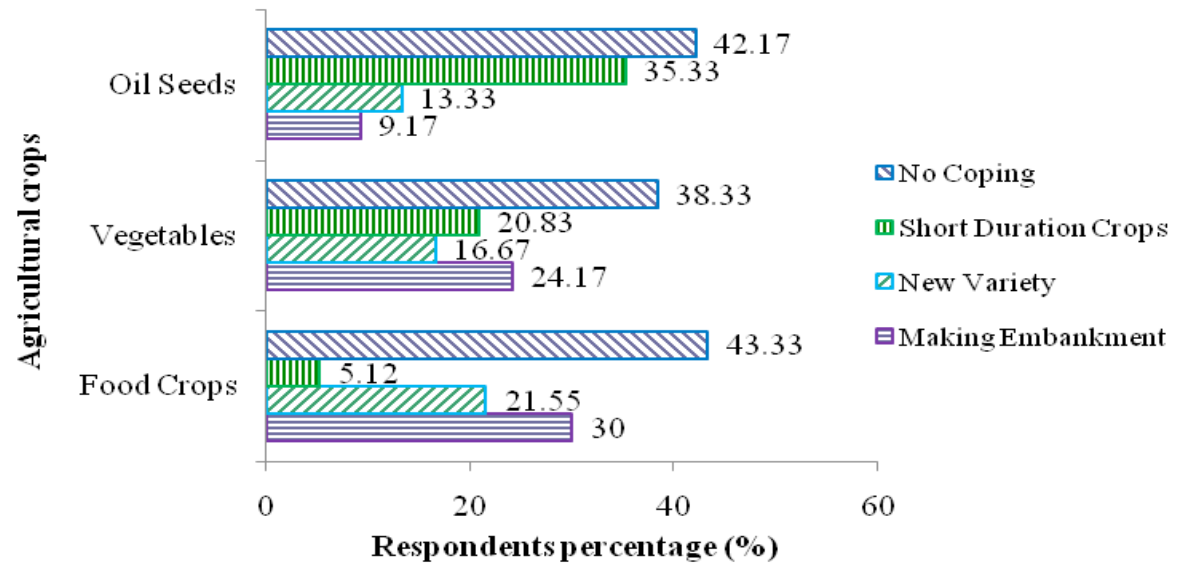

Fig. 6: Adaptation and coping strategies to sustain the agriculture in the study area; [Source: Questionnaire survey, 2014] 
Major Causes and Factors for Changing of Agricultural Practices in the Study Area

It is true and fact that vegetable and fruit cultivations are being popular and these types of culture are demanding cultivation practices in course of time due to high yield variety and short duration and huge demand. High productivity and gradual increase of demand encouraged soybean cultivation in these areas. Mustard and ground nut were also cultivated besides soybean. Food crops varieties were almost similar to the past. Several major causes have been indentified for these types of changing of agricultural practices in the study area. In this regards the climate change issue has been identified as the main factors for changing of agricultural practices in the study area as well as in the whole Bangladesh. Sarker and Hossain ${ }^{57}$ had also tried to prove that the whole agricultural system and practices of Bangladesh is being affected due the climatic instability and changing behavior. According to opinions of the respondent, the identified major causes are shown in the Fig. 3.

It is observed from the fig. 3 that the 'loss of land' was one of the prime causes or responsible issue for changing of agricultural practices in the study area. This issue is operated by the various ways; such as land degradation, agricultural land shifted by the urban land or settlement and directly coastal land or islands are disappeared through sea level rise which is directly or indirectly associated with climate change issue for the study area as well as in the coastal Bangladesh. On the other two causes 'River Bank Erosion and Increase of Soil

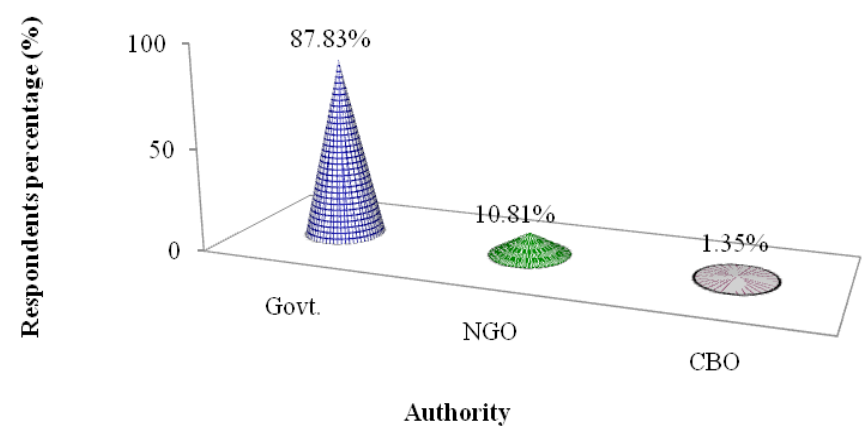

Fig. 7: Initiatives taken by the different authorities for coping strategy against climate change induced disasters in study area; [Source: Questionnaire survey, 2014]

Table 2: Respondents' perceptions on specific climate change events from the last forty years in the study area

\begin{tabular}{lcccc}
\hline Events of climate change & \multicolumn{4}{c}{ Perceptions to changing level of climate } \\
& $\begin{array}{c}\text { Increase } \\
\text { ( }(\%)\end{array}$ & $\begin{array}{c}\text { No change } \\
\boldsymbol{f}(\%)\end{array}$ & $\begin{array}{c}\text { Decrease } \\
\text { (\%) }\end{array}$ & $\begin{array}{c}\text { Don't know } \\
\boldsymbol{f}(\%)\end{array}$ \\
\hline Temperature & $120(100)$ & - & - & - \\
Rainfall & - & $4(3.4)$ & $116(96.6)$ & - \\
Drought & $120(100)$ & - & - & - \\
Flood & $120(100)$ & - & - & - \\
Cyclones & $120(100)$ & - & - & - \\
Salinity intrusion & $103(85.5)$ & $17(14.5)$ & - & - \\
Rain less winter season & $102(85.2)$ & $6(4.6)$ & - & $12(10.2)$ \\
Long summer season & $110(92.0)$ & $3(2.3)$ & - & $7(5.7)$ \\
Unpredictable rainfall & $109(90.9)$ & $1(1.1)$ & - & $10(8)$ \\
Changing the monsoon & $97(80.7)$ & $3(2.3)$ & - & $20(17)$ \\
\hline
\end{tabular}

Source: Questionnaire survey, 2014; [ $f=$ number of frequency] 
Salinity' are also directly responsible for changing of agricultural practices in the study area. The coastal river and liner settlement with cultivable land area of river bank are gradually decreasing through the processes of weathering and erosion by the river system in the context of Bangladesh. Simultaneously, salinity intrusion is a severe cause for changing of agricultural practices in the study area which is also related with flow of water and climate change issue.

According to opinions of the respondent, some major negative causes were identified which are responsible for low production of crops in the context of the study area. These are shown in the Fig.4.

The above fig. 4 also reveals that the natural phenomenons which are related to climatic issue were seemed to be responsible for the low or negative production of crops in the study area. It was assumed from the survey that agricultural production was being negatively changed in the study area and maximum $(73.33 \%)$ of the respondents reported that their agricultural production level and system is decreasing due the various climatic unusual behaviors such as extreme hot summer, sometimes heavy rain fall, unexpected flood and cyclone etc. It is also notable that the study area is mostly coastal based, the largest part of the areas is highly affected by flood and river bank erosion. A major portion of the respondents about $36.67 \%$ claimed river bank erosion as the prime cause or responsible for the negative changes of agricultural production in the study area followed by flood, cyclonic storm, salinity intrusion and drought with the relative opinions as percentage of $21.13 \%, 20.83 \%, 15.57 \%$ and $5.8 \%$ respectively (Fig. 4). Regarding this issue, previous records also confirmed that some negative events such as; cyclone, excessive rainfall and river bank erosion were responsible for decreasing production of crops in the study area. In 2013, as a result of cyclone 'MOHASEN' and excessive rainfall the production of some crops were decreased by 13321 Metric Tons in the study area ${ }^{62}$. Sikder ${ }^{63}$ also found in an investigation that the crop yield had been negatively impacted by flooding, droughts, salinity intrusion in these areas.

\section{Perceived Adverse Effects of Climate Changes on Agricultural Crops and Cultivation}

It is a long time processes to find out the direct adverse effects of climate change oriented on local agricultural crops and cultivation. It should to be needed long time record based data sheet to know causal effects of climate change on coastal agricultural crop production in the contexts of Bangladesh. To know the visible effects of climate change on the local agriculture the old aged farmers' observations and their experiences were considered. About 5700 hectares of agricultural land in this district are fully or partially affected by salinity ${ }^{64}$. Moreover, various co-factors are responsible to lose and erode the surface soil and also lose of soil productivity in the coastal areas of Lakshmipur district. The present study reviewed that climate change induced disasters such as river bank erosion and storm surges were acted as negatively on agricultural crops in the study area. Food crops and oil seeds were mostly affected as important agricultural crops due to climate change oriented disasters. According to opinions of the respondent and expert opinions survey, a perception based observation and visible effects of climate change on the local agriculture and crop productions of the study area are shown in the Fig.5.

It is observed from the above fig. 5 that food crops, vegetables and oil seeds are going to be affected in different ways. According to the opinion survey, food crops $(30.83 \%)$, vegetables $(48.33 \%)$ and oil seeds (47.5\%) were affected through excessive crop damage by the climate change induced disasters in the study area (Fig.5). Accordingly, food crops $(12.51 \%)$, vegetables $(29.17 \%)$ and oil seeds (18.07\%) were affected through lost of land productivity and simultaneously, food crops $(56.66 \%)$, vegetables $(22.5 \%)$ and oil seeds $(34.34 \%)$ were also affected through low production capacity by the climate change induced disasters in the study area (Fig.5). An earlier study conducted by Sarker and Hossain ${ }^{57}$ had also found that agricultural land was losing and food crisis was creating in the coastal areas of Bangladesh due to river bank erosion, saline water intrusion and other unusual disasters which are related to climate changes and threatened on whole agricultural system on coastal Bangladesh. 
Adaptation and Coping Strategies for Agricultural Practices Due to Climate Changes

Adaptation refers to the adjustment in ecological, economic, social and human systems in response to actual and expected climatic changes and impacts ${ }^{16}$. It involves learning to manage new risks and strengthening resilience in the face of change ${ }^{20}$. Coastal communities are struggling to cope with the existing challenge of climate shocks but climate change could push backward beyond their ability to cope ${ }^{65}$. By strengthening coping capacities can enhance the flexibility of a community against the effects of climatic hazards. So, it is essential to know how coastal communities are adjusting themselves against climate change through indigenous methods used in agricultural practices of the study area. According to opinions of the respondent, the adaptation and coping strategies which were already been introduced through cultural assimilation by the local farmers in the context of the study area are shown in the Fig.6.

It is found from the study that a significant portion of respondents or stakeholders did not use any coping strategies to sustain their oil seeds, vegetables and food crops [in oil seeds (42.17\%), vegetables (38.33\%) and food crops (43.33\%) respondents] in the study area in response to climate change (Fig. 6). Therefore, the farmers in the study area were tried to adopt some coping strategies through their inherited knowledge and practices i.e. Cultivation of short duration crops [oil seeds $(35.33 \%)$, vegetables $(20.83 \%)$ and food crops (5.18\%) respondents] and introduction of new verities [on oil seeds (13.33\%), vegetables (16.67\%) and food crops (21.55\%) respondents] (Fig.6).

It is also observed from the study that about $47.5 \%$ respondents used to adopt moderate coping strategy and 35\% respondents used to adopt low coping strategy on agricultural practices regarding the climate change effect the context of the study area. The present study also found that some initiatives had been taken by the Government and NGOs at local levels for coping with ultimate climate change in the coastal area of Bangladesh. A comparative scenario of adaptation and coping strategies which were familiar by the local farmer for crop production during the last few decades in the study are shown in the Fig.7.

According to opinion of the respondents, most of the initiatives had been taken by government (87.83\%) and followed by NGOs (10.81\%) and CBO $(1.35 \%)$ in the study area (Fig. 7$)$. It is also observed from the survey that the government level initiatives for coping with climate changes were included by the making of embankment, supplying good seeds and giving loan to the poor and landless farmer. The NGOs initiatives were limited in supply of good seeds and giving small scale loan as micro credits to the farmer and those also done by CommunityBased Organization (CBO) but in a small scale. On the other hand, some obstructions were identified from the present survey through respondents' opinions in protecting their cultivated land and also crops. The major obstacles were comprised with River bank erosion, shortage of embankments, lack of irrigation facility and unusual massive flood. Some less obstruction were also identified by the respondents' opinions such as tidal surge and improper maintenance of embankments for sustainable agricultural practices and management against the ultimate climate change effects in the context of the study area.

\section{CONCLUSION}

Vulnerability of coastal areas of Bangladesh is well recognized to climate change issue. Lack of institutional and financial support to deal with climate change in the coastal area of Bangladesh is greatly affecting the coastal people. Present research proposed some probable future coping strategies in response to climate change in the Lakshmipur coastal area of Bangladesh. People at the vulnerable areas need to adopt different strategies (i.e. adoption of short duration crops, new variety and making embankment as per agricultural crop cultivation) to minimize the effects of climate change.

\section{ACKNOWLEDGEMENTS}

Authors would like to thank the authority of Bangladesh Meteorological Department (BMD) for their assistance to access their record regarding climatic data. 


\section{REFERENCES}

1. Ministry of Finance (MoF), 'People's Republic of Bangladesh', Bangladesh Economic Review, 65 (2011).

2. Uddin, M. 'Assessing Long-term Impacts of Vulnerabilities on Crop Production Due to Climate Change in the Coastal Areas of Bangladesh', (November) (2010).

3. Akanda, M. G. R. \& Howlader, M. S. 'Coastal farmers' perception of climate change effects on agriculture at Galachipa upazila under Patuakhali district of Bangladesh', Global journal of science frontier research: $D$ agriculture and veterinary, 15(4), 31-39 (2015).

4. Bangladesh Bureau of Statistics (BBS), 'Statistical Year Book of Bangladesh, Bureau of Statistics, Planning Division, Ministry of Planning', Government of the Peoples's Republic of Bangladesh (2012).

5. Mobassarul, K., Hoque, Z. \& Upal, M. 'Impact of Climate Change on Coastal Community of Bangladesh', from Fourth South Asia Water Resource Conference, May 2009, Kathmandu, Nepal (2009).

6. Bangladesh Bureau of Statistics (BBS), 'Statistical year book of Bangladesh. Bangladesh Bureau of Statistics, Ministry of Planning', Government of Bangladesh, Dhaka, (2011).

7. Mahmood, S. A. I. 'Impact of Climate Change in Bangladesh:The Role of Public Administration and Government's Integrity', Journal of Ecology and the Natural Environment, 4(8), 223-240 (2012). http://dx.doi.org/10.5897/ JENE11.088

8. Ahmed, A. U. 'Bangladesh: Climate Change Impacts and Vulnerability', Climate Change Cell, Bangladesh, pp. 42 (2006).

9. Climate Change Cell, 'Climate Change and Bangladesh', published with support from Comprehensive Disaster management programme of the Government of the People's Republic of Bangladesh and its development partners, UNDP and DFID (2006).

10. Climate Change Cell, 'Climate Change and Bangladesh', published with support from Comprehensive Disaster management programme of the Government of the People's
Republic of Bangladesh and its development partners, UNDP and DFID (2007).

11. Basak, J. K., 'Climate Change Impacts on Rice Production in Bangladesh: Results from a Model', Unnayan Onneshan-The Innovators (2012).

12. Uddin, M. E. 'Household Food Security Status of Marginal Farmers in Selected Storm Surge Prone Coastal Area of Bangladesh', The Agriculturist, 10(1), 98-103 (2012).

13. World Bank, 'Bangladesh: Climate Change and Sustainable Development', Report No. 21104- BD, Rural Development Unit, South Asia Region, The World Bank, Dhaka, pp. 95 (2000).

14. Intergovernmental Panel on Climate Change (IPCC) Online, 'Glossary of Terms used in the IPCC Third Assessment Report' (2001).

15. Mohal, N. \& Hossain, M. M. A. 'Investigating the impact of relative sea level rise on coastal communities and their livelihoods in Bangladesh', Draft Final Report. Dhaka: Institute of Water Modelling (IWM) and Center for Environmental and Geographic Information Services (CEGIS). Submitted to UK Department for Environment Food and Rural Affairs in May 2007 (2007).

16. Intergovernmental Panel on Climate Change (IPCC), 'Impacts, Adaptations and Vulnerability', Cambridge: Contribution of Working Group II to the Fourth Assessment Report of IPCC on Climate Change, 2007 (2007).

17. BUP-CEARS-CRU, 'Bangladesh: Greenhouse Effect and Climate Change, Briefing Documents No. 1-7', Bangladesh Unnayan Parishad (BUP), Centre for environmental and Resource Studies (CEARS), University of Waikato, New Zealand and Climate Research Unit (CRU), University of East Anglia, Norwich, UK (1994).

18. Shahid, S. 'Probable Impacts of Climate Change On Public Health in Bangladesh', Asia- Pacific Journal of Public Health / AsiaPacific Academic Consortium for Public Health, 22(3), 310-319 (2010). http://dx.doi. org/10.1177/1010539509335499

19. Thurlow, J., Dorosh, P. \& Yu, W. 'A 
Stochastic Simulation Approach to Estimating the Economic Impacts of Climate Change in Bangladesh', Review of Development Economics, 16 (3), 412-428 (2012). http://dx.doi.org/10.1111/j.14679361.2012.00671.x

20. Food and Agriculture Organization of the United Nations (FAO), 'Community Based Adaptation in Action: A case study from Bangladesh', Project Summary Report (Phase I), Improved Adaptive Capacity to Climate Change for Sustainable Livelihoods in the Agriculture Sector, Food and Agriculture Organization of the United Nations, Rome (2008).

21. Murshid, K. A. S. 'Weather, New Technology and Instability in Food grain Production in Bangladesh', The Bangladesh Development Studies, 15(1), 31-56 (1987).

22. Rahman, M. H. 'Responding to drought in Bangladesh', The daily Star, MAY 15, 8 (1995).

23. Bangladesh Bureau of Statistics (BBS), The Bangladesh Census of Agriculture and Livestock: 1983-84, Structure of Agricultural Holdings and Livestock Population. Dhaka, (1986).

24. Government of the People's Republic of Bangladesh (GoB), 'National Adaptation Programme of Action (NAPA)', Final report: November 2005, Ministry of Environment and Forest, Dhaka, 48 p (2005).

25. Ahmed, A. U. \& Mirza, M. M. Q. 'Review of Causes and Dimensions of Floods with Particular Reference to Flood '98: National Perspectives". In Q.K. Ahmad, A. K. A. Chowdhury, S.H. Imam, M. Sarker, (Eds.), (2000).

26. Choudhury, A. M., Quadir, D. A., Neelormi, S. \& Ahmed, A. U. 'Climate Change and Its Impacts on Water Resources of Bangladesh', in A. Muhammed (ed.), Climate Change and water Resources in South Asia, Asianics AgroDev International, Islamabad, pp. 21-60 (2003).

27. Karim, Z., Hussain, S. G. \& Ahmed, M. 'Assessing impacts of climate variations on food grain production in Bangladesh', Water, Air, and Soil Pollution, 92, 53-62 (1996). http:// dx.doi.org/10.1007/BF00175552
28. Rahman, A. \& Alam, M. 'Mainstreaming adaptation to climate change in least developed countries (LDCs)', Working paper II: Bangladesh Country case Study of IIED in London (2003).

29. Ali, A. 'Vulnerability of Bangladesh Coastal Region to Climate Change with Adaptation Option', Bangladesh Space Research and Remote Sensing Organization (SPARRSO), Dhaka, (2005).

30. Haider, R., Rahman, A. A. \& Huq, S., (eds.), 'Cyclone '91: An Environmental and Perceptional Study', Bangladesh Centre for Advanced Studies, Dhaka, 91 pp (1991).

31. Parvin, G. A., Takahashi, F. \& Shaw, R. 'Coastal hazards and community-coping methods in Bangladesh', Journal of coastal conservation, 12, 181-193 (2008). http:// dx.doi.org/10.1007/s11852-009-0044-0

32. Government of the People's Republic of Bangladesh (GoB), 'Cyclone SIDR in Bangladesh: Damage, Loss, and Needs Assessment for Disaster Recovery and Reconstruction', A Report Prepared by the Government of the People's Republic Bangladesh Assisted by the International Development Community with Financial Support from the European Commission, April 2008, Dhaka, Bangladesh (2008).

33. Alam, M. 'Adverse Impacts of Climate Change on Development of Bangladesh: Integrating Adaptation into Politics and Activities', (CLACC working paper No. 1, Bangladesh). Dhaka: Bangladesh Centre for Advanced Studies, (2004).

34. Huq, S. 'Climate change and Bangladesh', Science, 23, 294 (5547), 1617 (2001). http:// dx.doi.org/10.1126/science.294.5547.161

35. Huq, S., Rahman, A., Konate, M., Sokona, Y. \& Reid, H. 'Mainstreaming Adaptation to Climate Change in Least Developed Countries (LDCs)', International Institute for Development, London, UK, 40 pp (2003).

36. Parry, M. L., Rosenzweig, C., Iglesias, A., Livermore, M. \& Fischer, G. 'Effects of climate change on global food production under SRES emissions and socioeconomic scenarios', Global Environmental Change, 14, 53-67 (2004). http://dx.doi.org/10.1016/j. gloenvcha.2011.01.015 
37. Agrawala, S., Ahmed, A. U., Smith, J. \& Aalst, M. V. 'Development and Climate Change in Bangladesh: Focus on Coastal Flooding and the Sundarbans', Organization for Economic Co-operation and Development (OECD) (2003).

38. Tanner, T. M., Hassan, A., Islam, K. M. N., Conway, D., Mechler, R., Ahmed, A.U. \& Alam, M. 'ORCHID: Piloting Climate Risk Screening in Bangladesh Detailed Research Report', Institute of Developmental Studies, University of Sussex, Brighton, UK (2007).

39. Maddison, D.'The perception and adaptation to climate change in Africa', CEEPA Discussion Paper No. 10. Centre for Environmental Economics and Policy in Africa, University of Pretoria, South Africa (2006).

40. Bangladesh Bureau of Statistics (BBS), 'Lakshmipur district statistics', Ministry of Planning, 32-33 (2011a).

41. Ministry of water resources (MoWR), 'Government of the People's Republic of Bangladesh, Coastal zone policy (2005).

42. Bangladesh Bureau of Statistics (BBS), 'Population and Housing Census, Ministry of Planning', Community Report on Lakshmipur Zila. 18, 22-23 (2011).

43. United States Agency for International Development (USAID), 'How resilient is your coastal community?', The United States Agency for International Development, US Indian Ocean Tsunami Warning System Program, Bangkok, pp 1-2 (2007).

44. Ali, A. \& Ahmad, A. A. Z. 'Impact of Sea Level Rise on Other Disasters in Bangladesh', presented at an IOC/UNEP Workshop on Impact of Sea Level Rise Due to Global Warming for the South Asian Region, 16 - 19 December, Dhaka, Bangladesh, (1992).

45. Department for International Development (DFID), 'Climate Change and Bangladesh', UNDP, Department of Environment, Bangladesh (2007).

46. Karim, Z., Ahmed, M., Hussain, S. G. \& Rashid, K. B. 'Impact of climate change on the production of modern rice in Bangladesh', Implications of Climate Change for International Agriculture: Crop Modeling Study. US Environmental Protection Agency, Washington D.C. (1994).
47. Karim, Z., Hussain, S. G. \& Ahmed, A U. 'Climate change vulnerability of crop agriculture', Vulnerability and Adaptation to Climate Change for Bangladesh. In: Huq, S., Karim, Z., Asaduzaman, M.,Mahtab, F. (Eds.), Kluwer Academic Publishers, Dordrecht, Netherlands, pp. 39-54 (1998).

48. Solomon, S., Qin, D., Manning, M., Chen, Z., Marquis, M., Averyt, K. B., Tignor, M. \& Miller, H. L., (eds.), 'Climate Change 2007: The Scientific Basis. Contribution of Working Group I to the Fourth Assessment Report of the Intergovernmental Panel on Climate Change', In: Solomon, S., et al. (Eds.). Cambridge University Press, Cambridge, U.K. 996 pp (2007).

49. Easterling, W. E., Aggarwal, P., Batima, P., Brander, K., Erda, L., Howden, M., Kirilenko, A., Morton, J., Soussana, J-F., Schmidhuber, J. \&Tubiello, F. 'Food, fibre and forest products', Climate Change 2007: Impacts, Adaptation and Vulnerability. Contribution of Working Group II to the Fourth Assessment Report of the Intergovernmental Panel on Climate Change, M.L. Parry, O.F. Canziani, J.P. Palutikof, P.J. van der Linden \& C.E. Hanson, (eds.), Cambridge, UK, Cambridge University Press, 273-313 (2007).

50. Hatfield, J., Boote, K., Fay, P., Hahn, L., Izaurralde, C., Kimball, B.A., Mader, T., Morgan, J., Ort, D., Polley, W., Thomson, A. \& Wolfe, D. 'Agriculture: From The effects of climate change on agriculture, land resources, water resources, and biodiversity', A Report by the U.S. Climate Change Science Program and the Subcommittee on Global Change Research. Washington, DC, USA, 362 pp (2008).

51. Basak, J. K., Ali, M. A., Islam, M. N. \& Alam, M. J. B. 'Assessment of the effect of climate change on boro rice production in Bangladesh using CERES-Rice model', In: Proceedings of the International conference on Climate Change Impacts and Adaptation Strategies for Bangladesh, 18-20 February. pp. 103-113 (2009).

52. SAARC Meteorological Research Council [SMRC], 'The Vulnerability Assessment of the SAARC Coastal Region due to Sea Level Rise: Bangladesh Case', 2013 (2013). 
53. Ali, K. M. B., Molla, M. H., Hossain, N., Hoshen, A., Rahman, M. \& Billah, M. M. 'Climate change induced disasters in the southeastern coastal belt of Bangladesh', Asian Journal of Water Environment, 2(1), 1-15 (2015).

54. Ali, A. 'Climate change impacts and adaptation assessment in Bangladesh', Climate Research, 12, 109-116 (1999). http://dx.doi. org/10.3354/cr012109

55. Sarwar, M. G. M. 'Impacts of Sea Level Rise on the Coastal Zone of Bangladesh', Master's thesis. Lund University, Sweden, 45 pp (2005).

56. Hassan, A., Chowdhury, J.U. \& Haque, A. 'Impact of climate change on riverine flooding in Bangladesh', Presented at the Final CLASIC Project Workshop, June $8^{\text {th }}, 2008$, BUET, Dhaka, Bangladesh, 16 pp (2008).

57. Sarker, S. \& Hossain., M. S. 'Climate change disaster and community based mitigation options at Ramgati coast, Bangladesh', Agricultural Science Research Journal, 2(6), 346-354 (2012).

58. Islam, M. R. 'Living in the coast: Problems, opportunities and challenges', Working Paper WP011,Dhaka. Programme Development Office (PDO) and Integrated Coastal Zone Management Plan (ICZMP). pp: 13-15 (2004).

59. Ahmed, A. U. \& Alam, M. 'Development of Climate Change Scenarios With General Circulation Models, in S. Huq, Z. Karim, M. Asaduzzaman, and F. Mahtab (Eds.),
Vulnerability and Adaptation to Climate Change for Bangladesh', Kluwer Academic Publishers, Dordrecht, pp. 13-20 (1998).

60. FAO/GIEWS Global Watch, 'Livelihood of over 8.9 million people adversely affected by Cyclone SIDR in Bangladesh', Accessed 21 December 2007 (2007). Available: http:// www.fao.org/giews/english/shortnews/ bangladesh071221.htm

61. Sayeed, S.K.'Climate change and Bangladesh: A perspective on where we are', The Daily Star. 13 October 2007:7 (2007).

62. Department of Agriculture Extension (DoAE), 'Draft Report on yield and loss of different crops', Ministry of Agriculture, Government of the People's Republic of Bangladesh (2014).

63. Sikder, M. T. 'The Impacts of Climate Change on the Coastal Belt of Bangladesh: An Investigation of Risks \& Adaptations on Agricultural Sector', Proc. of International Conference on Environmental Aspects of Bangladesh (ICEAB10), Sept. 2010- 26 -CC04, Japan (2010).

64. Cline, W. R. 'Global Warming and Agriculture: Impact Estimates by Country', Centre for Global Development and the Peterson Institute for International Economics (2007).

65. Reid, H., Alam, M., Berger, R., Cannon, T., Huq, S. \& Milligan, A. 'Community-adaptation to climate change: An Overview', pp 11. In: IIED. Participatory Learning and Action. Community-based Adaptation to Climate Change (2009). 